\title{
A proposal for management of migraine in dental clinic
}

\author{
YounJung Park, Hye-Jin Lee, Seong Taek Kim* \\ Department of Orofacial Pain and Oral Medicine, Yonsei University College of Dentistry, Seoul, Republic of Korea
}

Management of migraine, one of common primary headache disorders, involves the diverse strategies non-pharmacological treatment, such as headache diary, lifestyle modification, regular exercise and relaxation, cognitive behavioral therapy and neurostimulation, and pharmacological treatment. Among the treatments, this review described a pharmacologic treatment of migraine, classified into acute and preventive treatment based on the severity and the frequency of headache. It introduced the way to optimize pharmacological treatment and updated the latest treatment for migraine. (J Dent Rehabil Appl Sci 2019;35(4):199205)

Key words: migraine; treatment; acute; preventive; principles

\section{서론}

두통은 국내 인구 중 $90 \%$ 이상이 일생에 한번 이상 겪 게 되는 질환으로, ${ }^{1}$ 치과의사도 임상에서 종종 두통 환자 를 접할 수 있다. 환자의 병력을 세심히 청취하고 기본적 인 두통의 증상을 제대로 파악하면 기저 질환에 의한 이 차두통(secondary headache)이 아닌 원발두통(primary headache)의 경우에는 진단 및 치료가 그리 어렵지 않 다. 두통 진단 시 국제두통질환분류(International Classification of Headache Disorders)에 대한 정식 개정판 $\mathrm{ICHD}-3 \beta$ 을 이해하는 것이 큰 도움이 되며, ${ }^{2}$ 본 교실에 서 편두통 진단에 대해 2016년 본 학회지에 기고한 바 있 다. ${ }^{3}$

이 중 편두통은 대표적인 원발두통질환으로 과민한 뇌 의 특성 그 자체로 인하여 두통이 발생하는 것으로 알려 져 있다. 국내 대학병원 신경과 두통초진환자군 분포에 서 가장 높은 비율인 약 $40 \%$ 에 해당되는 흔한 질환이 며, 국내 편두통 유병률은 $6 \%$ 로 알려졌다. ${ }^{4}$ 편두통에 대 한 치료는 크게 약물치료와 비약물치료로 나뉠 수 있고,

*Correspondence to: Seong Taek Kim

Professor, Department of Orofacial Pain and Oral Medicine, Yonsei University College of Dentistry, Yonsei-ro 50-1, Seodaemun-gu, Seoul, 03722, Republic of Korea Tel: +82-2-2228-3110, Fax: +82-2-393-8076, E-mail: k8756050@yuhs.ac Received: September 10, 2019/Last Revision: October 18, 2019/Accepted: October 22, 2019
비약물치료에는 두통 일기 작성, 생활습관 개선, 운동 및 이완요법, 인지행동요법(cognitive behavioral therapy, $\mathrm{CBT})$, 신경자극요법 등이 포함된다. 본 종설은 그 중에 서도 주로 치과임상에서 편두통의 약물치료에 대해 알아 보고자 한다.

\section{문헌고찰}

편두통의 진단은 전적으로 병력 청취에 의존하기 때문 에 진단이 쉽지만은 않다. 하지만 편두통은 원발두통이 므로 초진에 확진하지 못하더라도 추가로 병력을 청취하 고 약물 치료에 대한 반응이나 두통의 변화 양상을 관찰 함으로써 최종적으로 진단을 내리기도 한다. 경도의 편 두통은 긴장형 두통과 임상 양상이 유사할 수 있어, 이 러한 경우에는 triptans와 같은 급성기 편두통 약제에 대 한 반응이 진단에 도움이 될 수 있다. ${ }^{5}$ 하지만 군발두통 (cluster headache)을 비롯한 거미막하출혈에 의한 이차 두통도 triptans에 의해 일시적으로 호전될 수 있으므로 주의가 필요하다. 두통빈도에 따라 두통일수가 한 달에

Copyright@ 2019 The Korean Academy of Stomatognathic Function and Occlusion. (c) It is identical to Creative Commons Non-Commercial License. 
15 일 이상이면서 그 기간이 3 개월을 초과하는 경우에 만 성편두통으로, 그 이하인 경우 삽화편두통으로 진단분류 된다.

편두통에 대한 약물 치료는 복용 방법에 따라 크게 급 성기치료와 예방치료로 나눌 수 있다. 그러나 편두통의 심도, 빈도, 특성의 개인차가 크고, 효능이나 부작용을 예 측할 만한 biomarker나 증상에 관한 profile이 아직 확립 되지 않아 각 환자의 최적 치료를 구현하는 것이 쉽지만 은 않다. ${ }^{6}$ 현재로서는 치료를 최적화하기 위해서는 환자 의 선호도, 임신/수유/임신계획 여부, 두통의 빈도와 심 도, 관련 증상의 종류와 심도, 두통과 연관된 장애 여부, 이전 치료에 대한 반응, 동반 전신병력과 복용 중인 약물 등을 고려해야 한다.

\section{급성기치료 (acute treatment)}

급성기치료의 목표는 급성 두통 발작을 중단시키고, 통증과 일상생활의 기능장애를 해소하는 데 있다. 두통 을 호소하는 환자라면 누구나 급성기치료를 시도해 볼 수 있다.

급성기치료 시 기본적인 지침을 하단에 소개하고자 한다. 근거가 확립된 급성기약물을 사용할 것; 많은 약물이 편두통 급성기치료에 사용되고 있으며, 2015년 미국 두 통 학회는 급성기약물의 근거 중심 분석 결과를 발표하 였다(Table 1). ${ }^{7}$ 효과가 입증된 약제로는 triptans, ergotamine derivatives, 비스테로이드항염제(nonsteroidal antiinflammatory drugs, NSAIDs) 중 aspirin, diclofenac, ibuprofen, naproxen 등이 있으며, 임상의는 두통의 심 도, 발현 기간 및 빈도, 동반 증상 등을 고려하여 각 개인
의 상태에 맞는 약을 처방함으로써, 부작용 없이 두통을 효과적으로 조절할 수 있는 급성기약제를 찾아주어야 한 다. 경도에서 중등도의 편두통 환자는 NSAIDs 혹은 acetaminophen 같은 단순 진통제나 caffeine이 첨가된 복 합 진통제(예: aspirin + acetaminophen + caffeine)를 일 차 약물로 사용한다. 두통 발작이 중등도 이상의 심한 환 자이거나 경험적으로 단순 진통제나 caffeine 첨가된 복 합 진통제에 반응이 떨어지는 환자는 편두통 특이 약물 인 triptans, dihydroergotamine (DHE)을 바로 처방한다.

두통 발작이 시작되면 빠르게 처치할 것; 통증이 시작 될 무렵이나 증상이 미약할 때 미리 진통제를 처방하는 조기치료는 매우 중요한데, 이는 두통 시작 후 중추성 감 작의 증거인 무해자극통증(allodynia)이 발생하게 되면 진통제를 투여하여도 두통개선률이 현저히 떨어지기 때 문이다. 따라서 진통제는 두통 발생 후 가능한 빨리(2시 간 이내) 복용해야 효과가 좋다. 환자에 따라서는 전구기 (premonitory phase)에 진통제를 투여하는 것을 고려해 볼 수 있다. 약 $75 \%$ 의 환자에서는 조짐(aura)과는 다른 증상인, 피로, 불안, 집중력 저하, 소화장애, 목의 뻣뻣함, 아플 것 같은 느낌 등의 전구증상이 나타나는데, ${ }^{8}$ 이때 진통제를 투여해서 효과적으로 두통이 조절될 경우 전구 기 투여를 권장할 수 있다.

심한 오심이나 구토를 보이는 환자에서는 비경구 투여 약제를 사용할 것; 심한 오심이나 구토를 동반하거나 경 구 투여 약제를 삼키기 어려운 환자에게는 비경구 약제 가 선호된다. 이 때 쓸 수 있는 약제로는 sumatriptan 피 하주사나 비강 흡입분무제, ketorolac 비강 혹은 근육주 사 등이 있다.

약물의 내성 및 안전성을 고려할 것; 환자의 동반 질환

Table 1. Assessment of acute medications for migraine ${ }^{7}$

\begin{tabular}{ll}
\hline \multicolumn{1}{c}{ Established efficacy $^{\mathrm{a}}$} & \multicolumn{1}{c}{ Probably effective } \\
\hline Triptans & Ergotamine and other forms of DHE \\
$\begin{array}{l}\text { Ergotamine derivatives } \\
\text { NSAIDs: aspirin, diclofenac, ibuprofen, naproxen }\end{array}$ & NSAIDs: ketoprofen, IV and IM ketorolac, flurbiprofen \\
Opioids: butorphanol & IV magnesium \\
Combination medications & Isometheptene-containing compounds $^{\mathrm{a}}$ \\
& Combinations: codeine/acetaminophen, tramadol/acetaminophen $^{\mathrm{b}}$ \\
& Antimetics: prochlorperazine, promethazine, droperidol, \\
& chlorpromazine, metoclopramide \\
\hline
\end{tabular}

DHE = dihydroergotamine; NSAIDs = nonsteroidal anti-inflammatory drugs; IV = intravenous; IM = intramuscular

${ }^{a}$ Consider single-pulse transcranial magnetic stimulation, noninvasive vagus nerve stimulation, or electrical trigeminal nerve stimulation in patients who prefer nondrug treatments of in whom drug treatment is ineffective, intolerable, or contraindicated.

${ }^{\mathrm{b}}$ In migraine with aura.

${ }^{\mathrm{c}}$ Use is not recommended. 
이나 투여 중인 약물을 고려하여 약물을 선택해야 한다. 예를 들어, NSAIDs의 경우 소화계나 심혈관계 부작용 을 일으킬 수 있고, triptans와 ergotamine derivatives는 심혈관계 질환자들에게는 주의를 요한다는 사실을 인지 하고 있어야 한다.

자가투여 구제약물의 사용을 고려할 것; 처방 받은 일 차 약제에 효과가 없을 경우 환자는 구제약제를 찾게 될 것이다. 심한 발작이 동반된 환자나 급성기약제에 반 응이 없거나 반응이 일관되지 않았던 환자의 경우에는, sumatriptan 피하주사, DHE 주사 혹은 비강 분무제, dexamethasone이나 ketorolac 근육 주사 등이 추천된다.

약물과용을 피할 것; 조기치료 및 효과적인 치료제의 의존 등으로 인해 진통제를 자주 복용하다보면 약물과 용을 초래할 수 있으므로, 복용횟수가 주당 2회를 넘지 않도록 해야한다. ICHD-3 $\beta$ 의 진단기준을 따르면 단순 진통제는 월 15 일 이상, 복합진통제나 편두통 특이약물 인 triptans와 ergotamine derivatives은 한달에 10 일을 초 과하여 3개월 이상 복용하는 경우, 약물과용두통으로 정 의하고 있다. 따라서 급성기치료 중 두통일기에 복용횟 수를 표시하도록 하여 위 기준을 넘지 않도록 환자 스스 로 모니터링하도록 하는 것이 추천된다.

\section{예방치료 (preventive treatment)}

편두통 환자의 약 $40 \%$ 는 예방치료가 필요하나 이 중 $3-13 \%$ 의 환자들만이 예방치료를 받는 것으로 보고되 어, 실제 임상에서 편두통 예방치료가 충분히 시행되지 않는 것으로 보인다. ${ }^{9}$ 예방치료를 시행하기에 앞서 이 치 료의 목적이 두통의 완전 관해가 아닌 두통 발작을 조절 하고 두통으로 인한 장애 정도를 줄이며, 효과가 없는 급 성기약물의 과용과 응급실 내원 빈도를 줄여서 삶의 질 을 개선하는 데 목적이 있음을 환자에게 설명해야 한다.

성인 삽화편두통 환자 중 예방치료 적응증에 해당되는 환자군은 아래와 같다.

- 급성기치료를 적절하게 시도했음에도 불구하고 편두 통으로 인하여 의미 있는 일상생활의 장애를 겪는 경우

- 월 4회 이상의 잦은 두통 발작 혹은 빈번한 두통 $(\geq 8$ MHDs)

- 급성기치료시 편두통이 효과적으로 치료되지 않거나 두통으로 인한 장애를 경험하는 경우

- 약물과용두통의 우려가 있는 경우

- 환자의 선호: 더 적은 두통 발작을 희망하는 경우
- 급성기치료의 의학적 금기를 가지고 있는 경우

예방치료 환자 선별시에는 발작 빈도와 두통과 관련된 장애 정도를 함께 고려해야 하며, 정상 생활 가능한 두통 이 월 6일 이상인 경우, 중등도의 장애를 동반한 두통이 월 4 - 5일 이상인 경우 및 심한 장애를 동반한 두통이 월 2 일 이상일 경우에는 편두통 예방치료가 반드시 필요하 다(Table 2).

편두통 발작이 제대로 제어되지 않을 경우 급성기약제 를 과용하거나 약물과용두통이 될 확률이 높아지며, 이 는 만성편두통으로 이어질 수 있다. 따라서 예방치료를 시행하기 전에 급성기약물의 종류나 투약 방법 등이 적 절하게 이뤄지고 있는지 재확인하고, 급성기치료와 함께 환자 교육 및 생활습관 개선 등의 비약물적 치료를 적절 히 병용해야 할 것이다. ${ }^{2}$

예방치료를 시작하고, 조절하고, 필요에 따라 종료함 에 있어 기본적인 지침을 하단에 소개하고자 한다.

근거가 확립된 예방약물을 사용할 것; 편두통 예방에 성공하려면 근거에 기초한 약물(Table 3)을 사용하는 것 이 매우 중요하다. 약물의 효능(efficacy)에 관한 근거 수 준과 American Academy of Neurology (AAN)에서 제 시한 근거 분류에 기초했을 때 다음 약제들은 그 효율이 입증되었다: 뇌전증약(divalproex sodium, valproate sodium, topiramate); 베타차단제(metoprolol, propranolol, timolol); frovatriptan(단기간만 월경 편두통에 사용). 이 중 valproate sodium과 topiramate는 기형유발의 위험 이 있으므로 가임기 여성에서는 유의해야 하며, 임신중 인 환자에서는 금기이다. 참고로 topiramate, divalproex sodium, propranolol과 nadolol은 편두통예방치료제로 국내 보험급여 인정기준에 포함되어 있으나, valproate

Table 2. Identifying patients for preventive treatment ${ }^{9}$

\begin{tabular}{|c|c|c|}
\hline $\begin{array}{l}\text { Prevention } \\
\text { should be }\end{array}$ & MHDs & $\begin{array}{c}\text { Degree of disability } \\
\text { required }^{\mathrm{a}}\end{array}$ \\
\hline Offered & $\begin{array}{l}\geq 6 \\
\geq 4 \\
\geq 3\end{array}$ & $\begin{array}{l}\text { None } \\
\text { Some } \\
\text { Severe }\end{array}$ \\
\hline Considered & $\begin{array}{c}4 \text { or } 5 \\
3 \\
2\end{array}$ & $\begin{array}{c}\text { None } \\
\text { Some } \\
\text { Moderate }\end{array}$ \\
\hline
\end{tabular}

MHDs = monthly headache days.

${ }^{a}$ As measured by scores on the Migraine Disability Assessment scale. ${ }^{12}$ 
Table 3. Assessment of preventive medications for migraine ${ }^{13}$

\begin{tabular}{|c|c|c|}
\hline Established efficacy & Probably effective & Possibly effective \\
\hline Antiepileptic drugs ${ }^{\mathrm{a}}$ & Antidepressants & ACE inhibitors: Lisinopril \\
\hline Divalproex sodium ${ }^{a}$ & Amitriptyline & $\alpha$-agonists \\
\hline Valproate sodium ${ }^{\mathrm{a}}$ & Venlafaxine & Clonidine \\
\hline Topiramate $^{a}$ & $\beta$-blockers & Guanfacine \\
\hline$\beta$-blockers & Atenolol & Antiepileptic drugs: Carbamazepine \\
\hline Metoprolol & Nadolol & $\beta$-blockers \\
\hline Propranolol & & Nebivolol \\
\hline Timolol & & Pindolol \\
\hline Triptans: Frovatriptan ${ }^{\mathrm{b}}$ & & Antihistamines: Cyproheptadine \\
\hline Onabotulinumtoxin $\mathrm{A}^{\mathrm{c}}$ & & Angiotensin receptor blockers: Candesartan \\
\hline
\end{tabular}

ACE = angiotensin-converting-enzyme.

${ }^{a}$ Not for use in women of childbearing potential who are not using an appropriate method of birth control.

${ }^{\mathrm{b}}$ Short-term prevention of menstrual migraine.

${ }^{\mathrm{c}}$ For prevention of chronic migraine.

sodium, 그 외 베타차단제는 현재 편두통 보험급여 인정 기준에 포함되어 있지 않다.

저용량에서 시작하고 서서히 조절하여 치료 용량까지 도달할 것; 선택된 약제는 저용량으로 시작하고, 부작용 을 피하거나 줄이기 위해 천천히 증량한다. 목표한 용량 에 도달하거나, 최적 효율이 나타나거나, 견디기 어려운 부작용이 동반된 경우라면 증량을 멈춘다. 만약 용량에 따른 부작용이 나타나지만 일부 반응이 확인되는 경우 에는, 다른 류의 예방약제와 병용 투여를 고려해볼 수 있 다.

치료 용량을 2 달 이상 유지할 것; 예방치료의 효능을 보기 위해서는 적정용량 혹은 최대 내약용량(maximal tolerable dose)으로 적어도 2개월 이상 복용이 유지되어 야 하며, 그 이후에도 효능이 부족한 경우에는 사용 중인 예방약물을 중단하고 다른 약물을 시도해 볼 수 있다. 예 방치료 후 편두통의 빈도나 두통일수가 $50 \%$ 이상 감소 하면 치료가 효과적이라고 판단하고 예방치료를 중단을 고려할 수 있다. 그러나, 예방치료가 효과적일 때 치료 기 간을 얼마나 지속할지에 대해서는 아직 근거가 부족하 여, 두통의 빈도 및 강도, 편두통이 일상생활에 미치는 영 향의 정도에 따라 환자마다 개별적으로 접근하는 것을 제안한다. 환자가 해당 약물을 복용하기 전에 발생 가능 한 흔한 부작용(예: valproate sodium 의 경우 구역, 과다 수면, 어지러움, 체중 증가 등, topiramate 의 경우 식욕 저하로 인한 체중 감소나 인지기능 장애 등) 혹은 흔치 않지만 심각한 부작용 등에 대해 이해한다면 복용을 유 지하는데 도움이 될 것이다.
약물 선택의 최적화; 약물의 효과, 환자의 선호도, 두통 의 특성, 동반된 질환의 존재 여부 등에 기본을 두고 약물 을 선택해야 한다. 이외에 환자에 따른 금기 약물 사용을 피해야 하고, 가임 연령기의 여성에서는 피임과 임신 시 약물의 잠재적 위험성에 대해 고려해야 한다.

주사형 제재는 경구 투여 약물보다 효과가 빠르게 나 타나고, 서서히 증량하지 않아도 된다. 그 중 Botulinum toxin 이 최근 많은 관심을 받고 있으며, onabotulinumtoxinA는 만성편두통 환자에서 그 효과가 입증되어 예방 목적으로 미국 Food and Drug Administration (FDA) 승인을 받았다. 약제의 기전은 onabotulinumtoxinA가 구심신경 섬유의 말초 종단에서 substance $\mathrm{P}$, calcitonin gene-related peptide (CGRP), glutamate를 포함한 통 각 매개물질들의 분비를 억제하며, 중추 삼차신경 혈관 계의 감작(sensitization)을 억제하는 것으로 추정하고 있 다. ${ }^{10}$ 머리와 목 부위 근육에 대한 31 개의 주사 부위에 155 unit의 onabotulinumtoxinA를 12주마다 주사하는 것이 권고된다(Fig. 1). 이외에 CGRP 를 표적에 둔 두 개 의 단일클론항체(fremanezumab and galcanezumab)와 CGRP 수용체에 표적을 둔 단일클론항체(erenumab)가 새롭게 대두되고 있는 예방적 주사치료제이며, 삽화 및 만성편두통 약제로 미국 FDA에서 승인을 받았다.

\section{이외의 비약물 치료}

신경자극요법(neuromodulation)은 전류나 자기를 이 용하여 중추 혹은 말초의 신경계를 자극하여 두통에 관 

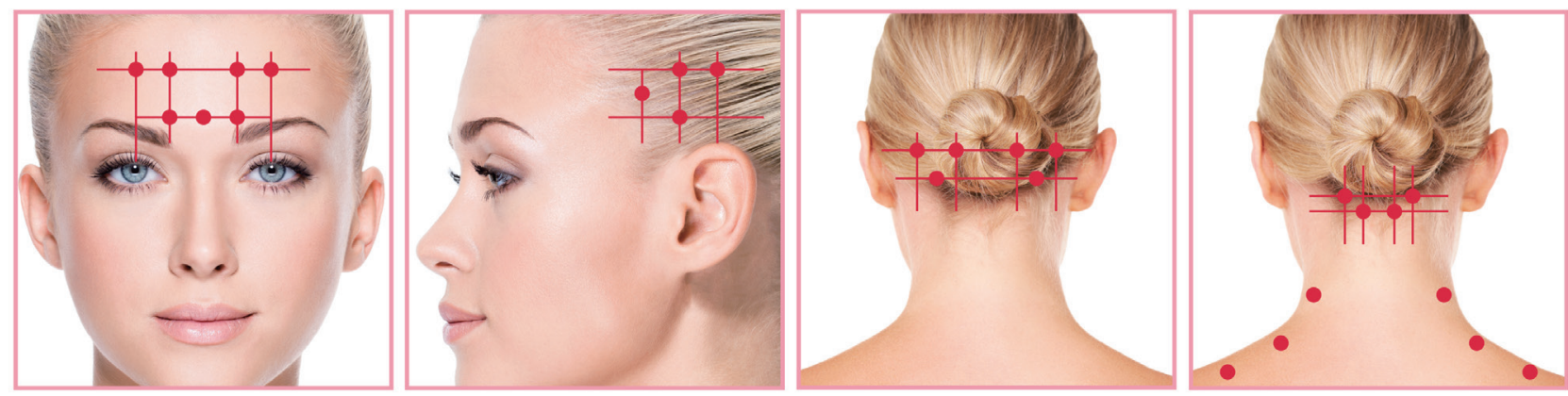

Fig. 1. This Allergan figure shows the injection sites for dispersing the $155 \mathrm{U}$ of OnabotulinumtoxinA. ${ }^{14}$

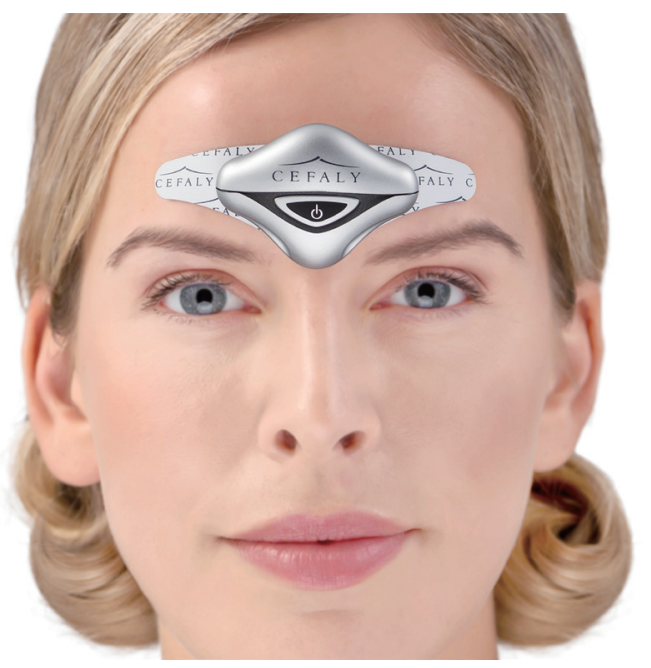

Fig. 2. Electrical trigeminal nerve stimulation, Cefaly ${ }^{\circledR}$ device. ${ }^{15}$

여하는 통증 메커니즘을 조절하는 치료이다. 전기삼 차신경자극술(electrical trigeminal nerve stimulation, Cefaly ${ }^{\circledR}$ device)과 단일자극두개경유자기자극술(singlepulse transcranial magnetic stimulation, Cerene/Spring mini transcranial magnetic stimulator ${ }^{\circledR}$ device)은 이미 미 국 FDA에서 급성기 및 예방치료로 승인되었으며(Fig. 2), 비침습적인 미주신경 자극요법(noninvasive vagus nerve stimulation, gammaCore noninvasive vagus nerve stimulator $^{\circledR}$ device)은 최근 급성편두통의 치료로 FDA승 인되었다. 이들 치료는 단독으로 혹은 약물치료에 추가 적으로 이용될 수 있으며, 약물치료가 금기되거나 반응 이 좋지 않은 환자들, 약물치료를 원치 않는 환자들에게 특히 효과적일 수 있다.
편두통의 급성기 및 예방치료 효과가 입증된 Grade A 에 해당되는 행동요법으로는 CBT, biofeedback, 이완요 법 등이 있으며, 임산부나 수유부 환자에게 좋은 치료대 안이 될 수 있다. 이외에 모든 편두통 환자들은 교육, 편 두통과 관련된 생활습관 개선을 통해 추가적인 치료효과 를 볼 수 있을 것이다.

\section{결론}

본 종설은 편두통 약물치료의 지침을 새롭게 갱신하 고, 급성기약물치료와 예방약물치료를 최적화하는 방안 에 관하여 기술하였다. 치과에 내원하는 환자들 중 정확 한 진단을 기반으로 한 원발 두통인 경우, 본 종설을 참 고하여 치과의사도 적극적으로 약물치료를 시도해 볼 수 있다. 즉, 치과에서도 유럽의 두통센터 체계 중 Level 1 에 해당하는 일차적인 두통 진료(general primary care) 를 충분히 담당할 수 있을 것이다. 이외에 진단이 복잡하 거나 조절이 어려운 환자, 당장 생명에 지장을 줄 수 있는 기질적인 원인을 동반하는 이차성 두통의 경우에는 두통 전문가가 있는 상위 기관(Level 2: special-interest headache care, Level 3: specialized headache center)으로 의 뢰해야 할 것이다. ${ }^{11}$ 본 종설이 치과에 내원하는 환자들의 편두통 진단과 치료에 도움이 될 것으로 사료되며 향후 이에 관한 후속 연구도 진행되어야 하겠다.

\section{References}

1. Lee TG CK, Chung KC, Choi JW. Prevalence of migraine in Korean adults: a nationwide survey. Korean J Headache 2000;1:57-66.

2. Headache Classification Committee of the Inter- 
national Headache Society (IHS) The International Classification of Headache Disorders, 3rd edition. Cephalalgia 2018;38:1-211.

3. Lee HJ, Kim YG, Kim ST. Diagnosis of headaches in dental clinic. J Dent Rehabil Appl Sci 2016;32: 102-8.

4. Kim BK, Cho SJ, Kim BS, Sohn JH, Kim SK, Cha MJ, Song TJ, Kim JM, Park JW, Chu MK, Park KY, Moon HS. Comprehensive Application of the International Classification of Headache Disorders Third Edition, Beta Version. J Korean Med Sci 2016;31:106-13.

5. Brennum J, Brinck T, Schriver L, Wanscher B, Sorensen PS, Tfelt-Hansen P, Olesen J. Sumatriptan has no clinically relevant effect in the treatment of episodic tension-type headache. Eur J Neurol 1996; $3: 23-8$

6. Silberstein SD. Practice parameter: evidence-based guidelines for migraine headache (an evidencebased review): report of the Quality Standards Subcommittee of the American Academy of Neurology. Neurology 2000;55:754-62.

7. Marmura MJ, Silberstein SD, Schwedt TJ. The acute treatment of migraine in adults: the american headache society evidence assessment of migraine pharmacotherapies. Headache 2015;55:3-20.

8. Laurell K, Artto V, Bendtsen L, Hagen K, Häggström J, Linde M, Söderström L, Tronvik E, Wessman M, Zwart JA, Kallela M. Premonitory symptoms in migraine: A cross-sectional study in 2714 persons. Cephalalgia 2016;36:951-9.

9. Lipton RB, Bigal ME, Diamond M, Freitag F, Reed ML, Stewart WF; AMPP Advisory Group. Mi- graine prevalence, disease burden, and the need for preventive therapy. Neurology 2007;68:343-9.

10. Ashkenazi A, Blumenfeld A. OnabotulinumtoxinA for the treatment of headache. Headache 2013;53 Suppl 2:54-61.

11. Steiner TJ, Göbel H, Jensen R, Lampl C, Paemeleire K, Linde M, Braschinsky M, Mitsikostas D, Gil-Gouveia R, Katsarava Z; European Headache Federation and Lifting The Burden: the Global Campaign against Headache. Headache service quality: the role of specialized headache centres within structured headache services, and suggested standards and criteria as centres of excellence. J Headache Pain 2019;20:24.

12. Stewart WF, Lipton RB, Dowson AJ, Sawyer J. Development and testing of the Migraine Disability Assessment (MIDAS) Questionnaire to assess headache-related disability. Neurology 2001;56:S208.

13. Silberstein SD, Holland S, Freitag F, Dodick DW, Argoff C, Ashman E; Quality Standards Subcommittee of the American Academy of Neurology and the American Headache Society. Evidencebased guideline update: pharmacologic treatment for episodic migraine prevention in adults: report of the Quality Standards Subcommittee of the American Academy of Neurology and the American Headache Society. Neurology 2012;78:1337-45.

14. BOTOX ${ }^{\circledR}$ Chronic Migraine Reconstitution and Injection Workshop Guide. In: Allergan I, editor; 2010.

15. Cefaly. Available from: https://www.cefaly.us/en/ migraine-treatment-cefaly (Updated 2019 Sep 4). 


\section{치과임상에서 편두통 치료에 대한 제안}

\section{박연정, 이혜진, 김성택*}

연세대학교 치과대학 구강내과학교실

흔한 중증 원발 두통 질환 중 하나인 편두통의 치료법에는 두통 일기 작성, 생활습관 개선, 운동 및 이완요법, 인지행동요 법, 신경자극 등을 비롯한 비약물치료와 약물치료 등 다양한 전략이 있다. 본 종설은 이 중 약물 치료를 두통의 강도와 빈 도에 기반하여 급성기치료와 예방치료로 나누어 고찰하고, 약물 치료의 효과를 극대화 시키기 위한 방법 및 편두통 치료 의 최신 지견을 소개하고자 한다.

(구강회복응용과학지 2019;35(4):199-205)

주요어: 편두통; 치료; 급성기; 예방; 지침 